\title{
THE LONG TERM GROUND LEASE: A SURVEY
}

INSUFFICIENCY of statistical analysis makes impossible any accurate estimate of the extent to which American property is held under long term ground leases. But fairly recent studies in metropolitan areas indicate that since the turn of the century there has been an almost continual upward rise in the number of these leases in downtown business districts. ${ }^{1}$ The increase in value of the property placed under long term leases serves as a further index of their growing importance. ${ }^{2}$ This Comment unclertakes to analyze the functions of this type of land tenure, ${ }^{3}$ and to weigh its efficacy in contrast with other available devices. ${ }^{4}$

Assistance in the preparation of factual materials contained in the footnotes wals furnished by personnel of the Works Progress Administration, Official Project No. 465-97-3-46.

1. See Fisher and Niehuss, Catalog of, Long Term Leases in Detroit (1929) 2 Mice. Bus. Studres Pamphlet 5, at 5. Though only twenty-six leases of twentyufive year terms or more were recorded in Detroit between 1834 and 1900, over 240 wcre placed on record between 1900 and 1929. In Chicago, there were a number of leases for twenty year terms and a few for as long as fifty years prior to the panic of 1873 . After the boom of 1890 , ninety-nine year leases came into vogue and their number has so increased that today almost half the business district of Chicago is held under such ground leases. Hoyt, One Hundred Years of Land Varues in Chicago (1933) 387. Another survey shows that between 1917 and 1938, 474 leases of fifty year terms or more were filed for record in the Chicago area. For an analysis of each of these lcasers see Long Term Leases (March 22, 1930) THE EConomist.

2. While in 1901 the value of Chicago property subject to long term leases was $\$ 2,381,500$, by 1925 this figure had risen to $\$ 33,562,000$. Hovт, op. cit. supra nota 1 , at 224. Some of New York City's most valuable developments, such as Roclicfeller Center, the Chrysler Building, the Waldorf-Astoria Hotel and Wanamalier's Store are held under long term leases. Ground leases apparently fell into disuse after the depress.ion of 1929. Egan, Effect of Depression an Ground Leases (June 1935) NATtONAL Rt:AL Estate Journal 53. But communications to Yale Law Journal from New Yort:, Chicago, Cleveland and Kansas City, Missouri realtors and attorneys indicate that this recession was temporary and that long term leasing is in a process of continual develope ment.

3. The scope of this Comment does not include specialized types of long term ground leases such as oil, gas, mineral and railroad leases for long periods. The splecific type of lease under observation is a device by which the owner of property turns it over to another person, the lessee, for the latter's full enjoyment and use, in return for which the lessee agrees to assume all the obligations which the owner of the fee would ordinarily bear and in addition pay him a stipulated rental. It is usual in a lease of this character to find elaborate provisions with respect to payment of taxes, insurance, security, malintenance and repair, rebuilding in case of involuntary destruction, assignment and sublerse, termination, appropriation, power to mortgage the leasehold or fee and, most particularly, an obligation, on the part of the lessee, to erect a building improvement. See generally Niehuss and Fisher, Problems of Long Term Leases (1930) 2 Mich. Bus. Stunrs Pamphlet 8.

4. "All around us are instances of legal devices that are made to serve rather roughly purposes for which they were never intended, simply because they contain an enforcement or security provision that looks efficient." See Isaacs, Business Security and Le'gol Security (1923) 37 HaRv. L. Rev. 201, 211. Much of our present property law is an 
The purposes which the long term leasing device has served since its inception in Anglo-American law have been remarkably diversified, but a thread of consistency in function runs through both its earlier and more recent history. Little is known of the extent or use of the lease before 1200, though its original purpose seems to have been the secret transfer of land to avoid the publicity attending livery of seisin." The first extensive employment of the device on record is allied with the extensiun of eredit, iur it arose as a method of avoiding the Church's prohilition against usury: ${ }^{\circ}$ it man of means would lend a needy landowner a sum of money, take in return his land for a term of years, and recover not only the principal amuunt of the loan but also the profits derived from the land during the term. ${ }^{7}$ Thungh long term leases continued to flourish, little more is heard of them until a new impetus led to an increase in their employment during the reign of Henry VIII. This time, the impetus arose out of the desire to aroill the consequences which the Statute of Uses inflicted upon a giit of land by way of use. ${ }^{8}$ Since uses limited on a legal term of years were held not to be within the purview of the Statute, ${ }^{9}$ the long term trust arose as the most expedient method of creating family settlements, and until the rise of moneyed securities, ${ }^{10}$ these trust terms were the chief concern of the English cuturts. In the United States, the earliest use of the long term ground lease is fuund in Maryland, where Lord Baltimore, the founder of the Maryland Culuny and original owner of all the land, initiated the ground lease system as the primary form of tenure. ${ }^{11}$ Its early popularity led to its survival and aduptiun in a few other states in somewhat different forms :22 but it was nut until

* outgrowth of English feudal principles. See Ralston Steel Car Co. v. Ralstun, 112 Ohio St. 306, 314, 147 N. E. 513, 516 (1925) ; Bennett, The Modern Lease (1937) 10 TEx. L. Rev. 47.

5. See Levy, Early History of Long Term Leases (Aug. 6, 1928) Natronal. Real. Estate Journal 57.

6. 2 Poliock and Maitland, History of Exclisir Lav (2d ed. 1923) 111; Plucknetr, A Concise History of the Cosiron Law (2d ed. 1936) 510. There was no usury when the lease was used because there was no "debt."

7. The line of demarcation between these beneficial leases, so-called, and a gage of land for years was quite indistinct, since both were used in the lending prucess. 2 Poliock and Maitland, History of Exglisir Law (2d ed. 1923) 121.

S. Bordwell, Interests in Chattels Real and Personal (1936) 1 Mlo. L. Rev. 119, 120; Levy, loc. cit. sipra note 5.

9. 7 Holdsworth, History of English LAw (2d ed. 1931) 129. The use of the trust term was criticized as a means of avoiding the incidents of feudal tenure. See Lampet's Case, 10 Co. Rep. at 52a (1612) ; 4 Holvsworru, op. cil. supru, at 472.

10. Bordwell, loc. cit. supra note 8.

11. See McMíchaer, Long and Short Term Leasenoldo (3d ed. 1925) 15 ef seq.; Levy, Long Term Leases and the Broker, Proceennas, Broker's Division, Natonosi. Real Estate Board (1924) 22, 24.

12. The ground rent system was used early in Ohio and Pennsylvania and its primary objective was home financing. See Franciscus v. Reigart, 4 Watts ( $\mathrm{Pa}$. 1835) 98, 117; St. Mary's Church v. Miles, 1 Whart. (Pa. 1836) 239, 235; Bngmas And Anonews, Financing Real Estate (1924) 184. 
approximately 1900 that the present general wave of long term ground leases began to sweep the country.

The two principal threads in the historical development of the ground lease-credit extension and family settlement-are important also in explaining its recent increase in popularity. The owner of a fee whose property is leased for a long period, ${ }^{13}$ secured by bond or improvements, and located in a district where land values are increasing, has a conservative, permanent real estate investment which will yield a fixed annual income., ${ }^{14}$ He is further enabled to keep title to the property in anticipation of an increment in value, and yet at the same time, to realize present income without stubjecting himself to the rigors of its development and management. ${ }^{15}$ It is little wonder, therefore, that with the rise of property values in urban centers, institutions, such as trust and insurance companies, universities and banks, employed the device freely. ${ }^{16}$ Then again, the ground lease offers a readily workable scheme for the individual owner of unimproved business property who desires a stable real estate investment or is tuable to realize potential sale value, or who for purely sentimental reasons does not wish to sell. ${ }^{17}$ In addition to these personal advantages; many owners have seized upon the lease device

13. Obviously, there is an economic minimum to the duration of a ground lease term, since the assumption of the leasehold obligations could not be undertaken unless a fairly long period within which to realize upon the investment were granted. The practice it1 individual communities varies. In Detroit, leases of ninety-nine years of the non-renewable type are the predominant vogue. Fisher and Niehuss, supra note 1, at 2, 5. In Ohio, such leases are renewable forever. Ralston Steel Car Co. v. Ralston, 112 Ohio St. 306, 147 N. E. 513 (1925). In New York, most terms run for twenty-one years with provision for renewals for additional terms of similar length. Two reasons have been advanced for the New York method. First, leases for more than twenty-one years were formerly taxable as personal property and the custom of limiting the term to avoid the tatx has prevailed. See Benson and North, Real Estate Principles and Practice (1938) 135. Second, because property in the business districts is continually increasing in value, owners hesitate to lease for longer periods. See Pryor, NINETY-Nine Yenk LuAsis AND Fortunes Made Therein (1928) 17.

On the other hand, there is no maximum, in the absence of statute, to the number of years leases may last. At least one state, however, has a limitation on the duration of agricultural leases. See N. D. Cosp. Laws ANN. (1913) $\$ 5289$ (10 year limit). Others have a general prohibition against leases over ninety-nine years. ALA. CodE (Arichie, 1928) §6923; Cal. Civ. Code (Deering, 1937) §718; Nev. Coup. Laws (Hillyer, $1929) \$ 1549$; N. D. Cosrp. Laws ANs. (1913) §5289. Under English Law of Property Acts of 1922 and 1925, $\S \S 145,202$, perpetually renewable leases then in existence or thereafter to take effect were converted into 2000 year terms.

14. See McMichael and Bingham, City Grow'th and Value (1923) 218; Momtu, Real Estate Seling and Leasing (1938) 514.

15. Fisher, Advanced Principles of Real Estate Practice (1930) 98.

16. See MrMichael and Binghan, loc. cit. sipra note 14 . Columbia University is the fee owner of the Rockefeller Center development in New York City. This investment is described in Pound, The Golden EarTh (1935) 249, in a chapter entitled "Alma Mater Prospera."

17. See Niehuss and Fisher, supra note 3, at 3; McMichaEk, op. cit. supra note 11, at 24 et seq. 
as a means of providing for their families in the future. ${ }^{18}$ Where the testator has left his estate in trust, the investment utility of the long term lease has been repeatedly recognized by the courts. In those cases in which the power of the trustee to lease beyond the duration of the trust has been questioned, the courts, in the absence of power expressly delegated by the testator, have seized upon phrases directing the trustee to "manage and control," "in "invest," "reinvest," "hold" and "exchange" 20 or "to lease generally"21 as empowering the trustee to enter into a long term lease. ${ }^{20}$ These phrases, however, are merely means to an end, an end which will not obtain unless the court is satisfied that the exigencies of the individual case warrant it;:3 and when so satisfied, courts have stretched the terms of the trust instrument to allow trustees to lease property for periods which may eren exceed the expiration of the trust. Occasionally, when changes unforeseeable to the testator have occurred, they have even permitted departure from express limitations on the power to lease. ${ }^{24}$

The recent swift rise in the number of long term leases may also be attributed in part to the income tax. One advantage of a lease over the sale of property lies in the fact that the owner retains his capital investment and aroids a tax upon its profitable sale.25 In place of a capital sum, the lessor receives a fixed income through rental payments, which, though subject to

18. Cf. Wagner v. Schrembs, 44 Ohio App. 44, 184 N. E. 292 (1932).

19. In re Gray's Estate, 196 Wis. 383, 220 N. W. 175 (1928); Upluam v. Planlinton, 152 Wis. 275,140 N. W. 5 (1913).

20. Marshall's Trustee v. Marshall, $225 \mathrm{Ky} .168,7$ S. W. (2d) 1062 (1923).

21. Collins and Bernard v. Foley, 63 Md. 158 (18s4). But cf. Hubbell v. Hubbell, 135 Iowa 637, 113 N. W. 512 (1907).

22. The general rule, however, seems to be that the trustee is without power to lease for a term extending beyond the life of the trust. Hubbell v. Hubbell, 135 Iowa 637, 113 N. W. 512 (1907); St. Louis Union Trust Co. v. Van Raslte, 214 1Fo. App. 172, 259 S. W. 1067 (1924) ; In re Caswell, 197 Wis. 327, 222 N. WV. 235 (1928) ; Comment (1930) 14 Mins. L. Rev. 274.

23. Marshall's Trustee v. Marshall, $225 \mathrm{Ky} .168,7 \mathrm{~S}$. WV. (2d) 1062 (1928); In re Gray's Estate, 196 Wis. 383, 220 N. W. 175 (1928). See Russell v. Russell, 109 Conn. 187, 199, 145 A. 648, 653 (1929) (building, seventy-five years old, was yielding a small income and a new $\$ 100,000$ building erected by lessee would yield $\$ 20,000$ annually).

24. Marsh v. Reed, 184 Ill. 263, 56 N. E. 306 (1900); Denegre v. Walker, 214 IIl. 113,73 N. E. 409 (1905). Under N. Y. Real Prop. LAW $\$ 106$, though a trustee is forbidden, without court approval, to lease for a term exceeding five years, the court may sanction a lease for a longer period if it appears that it will be in the best interests of the trust estate.

25. Taggert, Real Property Leases and the Income Tar (1932) 4 Mrren. Bus. Studies Pamphlet 2; Bingeax -ANd ANDrews, op. cit. stlpra note 12, at 292. No profit or loss is realized when the owner sells the fee and takes bacl: a ninety-nine year lease. I. T. 2679, XII-1 CuM. Bulc. 103 (1933). The lessee, also, derives advantage in that he can deduct the yearly rentals from his taxable income whereas if he had bought the fee, the amount invested would have no effect on such income save for mortgage interest.

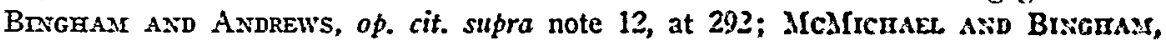
op. cit. sipra note 14 , at 285 . 
income tax, theoretically will not increase his net income; for if he had sold outright and invested the funds elsewhere, he would be taxed both on the sale and on the income from his new investment. ${ }^{26}$ By the recent elaborate amendments to the capital gain and loss sections of the Revenue Act, ${ }^{27}$ the percentage of the gain or loss which is to be taken into consideration in computing net income is fixed at fifty percent for all capital assets held over two years, no matter how long they have been held. ${ }^{28}$ It has been stiggested that through the new provisions, holders of long term capital assets which have fallen in value can realize considerable tax savings if they sell now and take the loss. ${ }^{29}$ This is concededly true; but it should be noted that in the case of business properties, where values tend usually to rise, capital gains upon sale will surpass capital losses. With the present fifty percent basis of computation, property owners will be even more disposed to lease than to sell. Of course, the owner may not sell his property outright but may resort to an installment sale, accorded special treatment under the Revenue Act. ${ }^{30}$ By this method he may avoid accounting for the entire profit in a single year and distribute his capital gains over a longer period. While such a distribution would tend to keep him in lower surtax brackets, the installment sale device is customarily of shorter duration than a long term lease, ${ }^{31}$ and hence it does not directly compete for favor with the lease as a method of reducing income taxation.

Two factors, deterrent in effect, however, face the land owner who contemplates using a long term lease as a method of tax avoidance. First, a decision to lease rather than sell, from the standpoint of income taxes, cannot be made without consideration of a host of problems which will affect his income should he choose the lease device. ${ }^{32}$ A lessor's gross income not only includes rent but may also embrace payments made by the lessee in the nature of a bonus, improvements made pursuant to the lease, periodic payments by the lessee in behalf of the lessor, such as taxes, interest on bonds

26. This, of course, presupposes that he does not invest the proceeds of the sale in tax exempt securities.

27. Pus. L. No. 554, 75th Cong., 3d Sess. (May 28, 1938) $\$ 117 ; 26$ U. S. C. (Supp. 1938) $\$ 101$.

28. For capital assets held less than 18 months, the percentage used in computing the net income is $100 \%$; for those held between 18 and 24 months, the percentage is $662 / 3 \%$. Under prior acts, the longer a capital asset was held, the smaller would be the percentage of the gain, or loss, used in the computation. Under the Revenue Act of 1936, for capital assets held less than a year, the percentage was $100 \%$, for one to two years, $80 \%$, for two to five years, $60 \%$, for five to ten years, $40 \%$, and over ten years, 30\%. 49 SтAт. 1691 (1936). Cf. the Revenue Act of 1921 where the percentage for capital assets held over two years was only $121 \frac{1}{2} \% .42$ STAT. 233 (1921).

29. 2 Paul and Mertens, Federal Inconse Taxation (Supp. 1938) 285.

30. Pub. L. No. 554, 75th Cong., 3d Sess. (May 28, 1938) §44; 26 U. S. C. (Supp. 1938) §44.

31. There is, however, no limit in the Revenue Act on the number of installments over which the gains or losses may be distributed.

32. See generally Taggert, stpra note 25 . 
and dividends to the lessor's stockholders, and increases in value of improvements by premature cancellation of the lease. ${ }^{33}$ Deductions that may affect the net income include advance payments by the lessor to produce the lease, unamortized cost of buildings razed, interest on indebtedness and taxes paid by the lessee, depreciation and improvements made by the lessor for the lessee's benefit. ${ }^{34}$ Whether the owner will benefit by lease or sale depends upon a forecast and evaluation of all the factors that may enter into each individual situation. Second, the lease's permanent utility as a means of tax avoidance may be questioned; with the Government constantly striving to close loopholes in the revenue laws through amendment, qualification and interpretation, it is quite possible that if the lease is too frequently utilized for this means, the gap in the present law will be filled.35

Though sound investment or income tax avoidance may have been motivating factors in the recent increase in ground leases, neither is more than an adjunct to the primary reason for this growth: the need for a flexible device to finance the development of business property. ${ }^{30} \mathrm{By}$ employment of the lease device, the lessee gets full use of the land without making a capital investment. The money which he would otherwise have spent to buy the property may be applied to pay the cost of improvements required by the

33. Id. at 163 et seq. The problem of whether improvements erected by the lessce constitute taxable income to the lessor has been a source of constant conflict since the enactment of the Income Tax Law. For a historical survey and review of the decisions on the question see Smith, Is the Value of Improzenents Made By a Lcssec Toxable Income to the Lessor? (1938) 16 TAx MLAG. 577. But recently the United States Supreme Court has settled some of the issues involved by repudiating the Treasury Department's depreciated value method of computing income and holding that cnhancement of the value of premises by improvements was not realized income to the lessor. Mr. E. Blatt Co. v. United States, 59 Sup. Ct. 185 (U. S. 1938).

34. Taggert, sipra note 25 , at 192 et seq.

35. Id. at 85 . There are tax problems, other than income tas, which may afiect the utility of the long term lease. In Detroit, for example, there are a number of leases on property used for business purposes upon which there is no property tax beause the fee is owned by the University of Dichigan which is tax exempt. Fisher and Nichuss, supra note 1 , at 6 . In most instances, however, it has been held that when the holder of the fee is exempt from taxation, the leasehold interest is taxable. Jetton v. University of the South, 208 U. S. 489 (1908); San Pedro L. A. \& S. L. R. R. v. Los Angeles, 180 Cal. 18, 179 P. 393 (1919); Chicago v. University of Chicago, 302 Ill. 455, 134 N. E. 723 (1922).

36. For an early but excellent statement of the financial function of the ground lease, see Banks v. Haskie, 45 Md. 207 (1876). See also Nichuss and Fisher, sspra note 3, author's note and page 3. For an interesting non-financial use of the long term lease, see Bristol v. Cornell University, 237 App. Div. 771, 263 N. Y. Supp. 380 (3d Dep't 1933) (growing university leased campus property to professor at nominal rent to induce his permanent residence). As a prerequisite to financing a business development, it is often necessary to acquire the necessary parcels from different owners. This accounts for a great many long term leases. See FisHER, op. cit. supra note 15, at 101. Stern Brothers Department Store Building in New York has been erected on property owned by two corporations, the Gerry Estates, Inc. and Fifth Ave. and 42d St., Inc. 
lease. ${ }^{37}$ In actual practice the procedure may not be quite so simple, for despite the loan of the property, the lessee may still have insufficient resources with which to meet the costs of building construction. As a restilt, the leasehold mortgage has appeared to aid in the financing process. ${ }^{38}$ In communities where ground leases are common, financial institutions will make loans on leaseholds and will even issue and sell bonds based upon them to investors..$^{30}$ To this procedure may be attributed much of the shoestring financing of boom times; a promoter of a building development, by means of a long term lease and a leasehold bond issue, may erect a building with little or no personal responsibility for costs of land, labor or materials. ${ }^{40}$ Nor is there dissent from the proposition that this method of financing may be matle an easy channel to speculative activity. Therein lies one of its chief dangers. On the other hand, if the enterprise is legitimate and the leasehold has an equity, conservative lending institutions are willing to concede that a leasehold mortgage is no more risky than any other junior lien. ${ }^{41} \Lambda$ s a matter of fact, mortgage lenders who limit their loans to fee interests have found themselves barred from a greater and greater percentage of the most prom ductive urban properties. ${ }^{42}$

Comparison should be made of the relative merits of the lease and the mortgage as methods of financing the development of property. ${ }^{43}$ Under the

37. NoRTH, op. cit. supra note 14 , at 515 . If the owner himself desires to improve his land, he may get a $100 \%$ loan by selling the fee to an investor and taking back a long term lease. See BrNgran and ANdrews, op. cit. silpra note 12, at 39 .

38. The lessor, too, may find himself unable to lend the full value of the land. This has precipitated the development of land trust certificates in a few jurisdictions. This device is most often used, however, in cases where a prospective buyer of real estate, who wants the benefit of a $100 \%$ loan, sells the fee to a financial institution and takes back a long term lease. The lender creates itself trustee by a declaration of trust and sells land trust certificates to the investing public. See Bingran aNd ANDREws, of. cit. supra note 12, at 196 et seq. No statistics are available on the extent to which this transaction is used.

39. See Bingham and Andrews, op. cit. supra note 12, at 40, 159; Morrison, Leaseholds as Security for Savings Bank Loans (June 23, 1930) National. Real Estate JoURNaL 29.

40. Hoyt, One Hundred Years of Land Values in Chicago (1933) 386; Krumrine, Long Time Leases (Jan. 9, 1928) Natronal Real Estate JounNal 41.

41. See Bingham AND ANdrews, op. cit. supra note 12, at 159. An analysis of 1500 long term leases has been made to determine the condition of the rentals and the incroment of rentals over and above their initial value. In the second year of the leases the average increment was $7 \%$ above the initial rental value; in the tenth year, it was $22 \%$; in the twentieth year, $.35 \%$; in the eightieth year $44 \%$. See Whittier, Long Term Lcascholds (Mar. 16, 1931) National Real Estate Journal 27.

42. Morrison, loc. cit. supra note 39.

43. The close relationship between the lease and the mortgage is illustrated in Posner Bros. v. Bayless, 59 Md. 56 (1882) where the Maryland redeemable ground rent device was identified as nothing more than a mortgage. For the historical development of the Maryland lease system see MCMrchaEd, op. cit. supra note 11 , at 15 et seq. It is interesting to note that in 1922, the Maryland legislature excepted from redemption those 
lease method, the borrower obtains a loan which is equivalent to $100 \%$ of the value of the land; were he to buy the property outright with the aid of a first mortgage, he could borrow ordinarily only up to fifty or sixty per cent of its value, not including discounts and commissions. ${ }^{44}$ Moreover, after the loan is placed, the mortgagor has the further burden of providing for amortization of the principal sum during the period of the loan; whereas, in the lease transaction, the return of the land to the owner at the expiration of the lease is equivalent to reimbursement of the principal sum. ${ }^{45}$ If a large sum is needed by the mortgagor, which will be the usual case in buying central business property, a bond issue attended with heavy financing charges -legal fees, trustee's fees, printing and engraving costs, underwriters' commissions and selling costs-will be necessary. ${ }^{40}$ But, in like manner, it is important for the lessee to consider security required of hin in the form of deposit or surety bond as an additional cost of financing the lease.ti In periods of money stringency, when lending banks are in the habit of calling loans or requiring them to be substantially reduced and the owner of the land must meet this demand at a time when money is scarce, the long term lease has an advantage over the mortgage device, since under the lease arrangement, the lessor can demand no more than the rental provided for in the lease. ${ }^{48}$ When there is need for advances in addition to those obtained through the first mortgage or lease, the borrower must resort to the field of junior financing; the mortgagor will negotiate for a second mortgage while the lessee will rely upon a first mortgage on his leasehold. In view of the current disrepute into which second mortgages have fallen, ${ }^{49}$ and the recent recognition of the first leasehold mortgage as a possible sound real estate investment, ${ }^{50}$ it may be easier for the lessee to obtain the additional funds. ${ }^{.1}$

leases entered into exclusively for business, commercial, mercantile and industrial purposes, provided the term of the lease did not exceed ninety-nine years. Min. As:z: ConE (Bagby, 1924), art. 21, \$99. Thus the legislature recognized the utility of long term leases in the development of business properties.

44. See Brookings Institute, First Míortgages in Urbais Real Estate Frinace (1929) 13. Where loans are placed to finance construction on undeveloped properties, the rates are likely to be one-half of one per cent, or more, higher. Ibid. For a comparative mathematical analysis of financing a building through the lease and mortgage methods see Krumrine, supra note 40 , at 40 .

45. Levy, The Long Tern Lease (Nov. 12, 1928) Natronar REal Estate JounNAL 54.

46. See Brookings Institute, supra note 44, at 55; Bngmasr Ard Asidrews, op. cif. sipra note 12 , at 259 et seq.

47. See note 72 , infra. The lessee will have to pay the costs of a professional surcty bond or if a security deposit is used, the lessor may be entitled to the interest from the securities during the period of the deposit.

48. MCMITCHAEL, op. cit. sipra note 11, at 29.

49. See generally Reep, Second Mortgages and Land Contracts mi Rear Estate Financing (1928); Binghays AND ANdrews, op. cit. supro note 12, at 158.

50. See Binghanr AND ANDrews, op. cit. supra note 12 , at 250 ct scq.

51. The leasehold mortgage, however, has by no means escaped the recent economic upheaval. "Prior to 1933 it was not difficult for the tenant to obtain a mortgage loan 
In terms of legal protection, the mortgage has had a more continuous history than the lease and has accordingly been surrounded with a more standardized system of remedies. The mortgage foreclosure has received the protracted scrutiny of both courts and legislatures, with the result that the remedies of both mortgagor and mortgagee have been largely crystallized. ${ }^{52}$ But the remedies under the lease have undergone no such crystallization, so that conflicting views on forfeiture, ${ }^{53}$ anticipatory breach, ${ }^{54}$ security enforcement ${ }^{\text {t5 }}$ and the like still raise speculations as to the enforceability of many lease terms. Moreover, in spite of the number of seeming advantages which the lease has over the first mortgage, the well established notion that the latter is the safest and highest type of real estate security gives it a psychological advantage in the eyes of many investors.

The chief value of the long term ground lease as an instrument for financing building development lies in its flexible nature, a pliancy which is reflected in a wide variety of provisions designed to protect the interests of both parties. Though all the terms of the ground lease are fashioned for use as a credit device, $^{56}$ the rental, security, assignment and termination provisions form

secured by a mortgage on the leasehold. But since the mortgage troubles commencing in 1933 it has become exceedingly difficult to finance the erection of the building if the security to the mortgagee is only a tenant's interest in a leasehold." Communication to YaLE LAW Journar from a New York City real estate attorney.

52. 1 Wittsie, Mortgage Foreclosure (1927) \$22 at scq.; Warsh, Mouttanges (1934) $\$ 65$.

53. There is no general statutory procedure to obtain a final adjudication of the parties' rights comparable to mortgage foreclosure by action. The various methods of enforcing forfeiture for breach of an express condition include simple re-entry, notice before re-entry or some judicial proceeding in the nature of ejectment. See 2 TxFysNY, LaNdLoRd AND TENant (1912) $\$ 194(\mathrm{j})$. But equity can be invoked and often steps in to prevent forfeiture. In $r e$ Hool Realty Co. 2 F. (2d) 334 (C. C. A. 7th, 1924) (sufficient deposit of security to cover rent due); Trefethen v. Hansen Mfg. Co., 155 Wash. 702, 284 Pac. 787 (1930) (30 day notice provided in lease suspends 3 day notice provided by unlawful detainer statute); Mayer v. Collins, 279 Ill. App. 439 (1935) (office of security and immediate erection of more valuable building after demolition of old, unsafe building).

54. There is a lingering notion in some states that the lessor cannot recover damages upon breach of the lease provisions until termination of the lease. Moore v. McDuffie, 71 F. (2d) 729 (C. C. A. 9th, 1934) ; Hermitage Co. v. Levine, 248 N. Y. 333, 162 N. E. 97 (1928); Phillips-Hollman v. Peerless Stages, 210 Cal. 253, 291 Pac. 178 (1930). Cf. Grayson v. Mixon, 176 Ark. 1123, 5 S. W. (2d) 312 (1928); Sagamore Corporation v. Willcutt, 120 Conn. 315, 180 At1. 464 (1935); Bennett, The Modern Lease (1937) 16 TEx. L. REV. 47.

55. See cases cited infra note 75 .

56. Limitation of space prevents discussion of provisions dealing with insurance, taxes, erection, maintenance and replacement of buildings, condemnation, power to mortgage leasehold and fee, subleasing, destruction of premises, etc. The cconomic and legal effect of all these clauses are of significance in considering the lease as an instrument of finance. For brief discussions of some of them see BINGHAar AND Andrews, op. cit. supra note 12, at 138 et seq.; Niehuss and Fisher, stpra note 3; Nortir, op. cit. supra note 14 , at 521 et seq. 
the fulcrum of the process. In determining the rent which the lessee is to pay, there is an ever-present controversy as to whether the landlord should be limited to rentals based upon present value of the property or should be allowed to participate in its possible future increase. The persistent feeling that a rental based upon the value of the land at the time of the lease is unfair may be attributed to the fact that the lessor, unlike the seller of property, continues to regard himself as the owmer, though he has parted with all present use and enjoyment save rent. ${ }^{57}$ This notion, together with the steady ascendance of land values, ${ }^{5 s}$ has led to the adoption of graded rentals, ${ }^{59}$ re-appraisal clauses ${ }^{60}$ and percentage provisions ${ }^{01}$ in many of the more recent ground leases. ${ }^{62}$ All these methods, which allow the owner to share in the possible land increment, have been attacked by those who clain that the tenant should be entitled to the gain which may accrue through his resourcefulness or a general rise in value, since he has assumed the burdens of developing the property. ${ }^{63}$ It is further argued that the re-appraisal method discourages improvements as each revaluation period approaches, ${ }^{64}$ and malies the initial financing of improvements more difficult, since financial institutions are hesitant to make loans on an equity which may be wiped out by an increase in rental, especially when such increase is caused by building im-

57. Niehuss and Fisher, supra note 3 , at 13.

58. Id. at 14. If in the future land values were to decline, a rental based on a percentage of the current land value would cause no objections on the part of lessors.

59. In graded leases, rentals are fixed at a set sum for a given number of years and then arbitrarily increased or, less frequently, diminished. The "minimum rentals" clause under the latest modification of the Stern Brothers store lease in Block 1258, New Yorl: City, provides for the following step-ups: 1935-36, \$130,000; 1936-37, \$137,500; 1937-38, $\$ 145,000 ; 1938-39, \$ 152,000 ; 1939-40, \$ 160,000 ; 1940-53, \$ 185,530$. See note 61 , infro, for the "additional rental" provisions.

60. When the re-appraisal method is employed, the property is revalued at stipulated intervals and the rent is increased or decreased upon the basis of the new valuation. Most of the leases in Block 1258, New York City, have twenty-one year renewal clauses and adopt a definite procedure for fixing new rentals. In case the parties cunnot agree, arbitrators are to be appointed by both parties for the purpose of appraising the value of the land, and, in some instances, the first six floors of the building. The rent is then based upon a percentage of the land and building value with a minimum rental guaranteed.

61. In the percentage lease, the lessee pays a yearly rental based upon a percentage of the annual volume of business done on the premises though a minimum rental is usually guaranteed.

62. In Detroit, of the 313 recorded leases through 1929, 74 had flat rental clauses, 12 had reappraisal clauses, 207 had graded rental clauses, 11 had some combination of these and 9 had no rental clause on record. Fisher and Nichuss, sipro note 1, at 5.

63. See Niehuss and Fisher, sipra note 3 , at 12. The use of the graded lease is commendable when the rentals, though based on the value of the property when leased, are distributed so that the lessee pays less during the time when he is to malie the improrements with a step-up thereafter. Id. at 16.

64. BIngHanr AND ANDREws, op. cit. supra note 12, at 266; Nichuss and Ficher, supra note 3 , at 17 . 
provements made possible by the very extension of the loan. ${ }^{65}$ Nevertheless, this form of rental clause is in vogue in New York and other Eastern cities. The percentage lease is a fairly recent development, has been used most frequently in chain store leases, and there is not yet sufficient information to determine its utility ${ }^{67}$ but the major trend is still in favor of a straight, fixed rental, the future of which necessarily depends upon the rise or fall of land values and the bargaining power between lessor and lessee.

Though many individuals may desire to lease for a long time where there is an opportunity for gain, they will be similarly desirous of evading their responsibility should fortune later turn against them. ${ }^{68}$ Hence there arises the need that some security be given the lessor, since he will not lend his land for a long period without some assurance, besides the lessee's personal responsibility, ${ }^{60}$ that rentals will be paid and the other covenants performed. In the lease transaction, this security takes its principal form in the buillingr to be erected by the lessee. ${ }^{70}$ Through the requirement that the tenant construct an improvement of stipulated value and quality, the lessor is made secure to the extent that he may claim forfeiture of the premises should the lessee default. ${ }^{71}$ In the interim period before construction, additional security is generally required and this customarily takes the form of a personal or surety bond ${ }^{72}$ or, more frequently, a deposit of security. ${ }^{73}$ The latter method,

65. In one instance, a corporate lessee, in order to finance a building under this type of lease, had to issue preferred stock and the president of the corporation had to personally guarantee payment of dividends when a bond house refused to underwrite a bond issuse on the proposed venture. See Binghans AND ANDREws, op. cit. sitpra note 12, at 266.

66. The lengthening of the period between appraisals has helped. See Niehuss and Fisher, supra note 3, at 20; Fisher, op. cit. supra note 15, at 90.

67. The percentage lease has been justified on the ground that it does away with problems arising out of the inability to determine a fair rental value for a long period. The volume of business, it is said, is a close index to the value of the premises. Sce North, op. cit. supra note 14, at 526; FisHER, op. cit. supra note 15, at 89.

68. "Long term leases seldom expire in St. Louis. The property either becomes more valuable or less valuable, and if more valuable, the lessee usually buys the fee, and if less valuable, the lease is usually forfeited." Communication to Yale LAw Journat from a.St. Louis Title Insurance Co.

69. See Wilson, Lease Security Deposits (1934) 34 CoL. L. Rev. 426. An exception is often made in the case of leading chain stores whose responsibility in executing the lease is sufficient. Ibid.

70. Id. at 430 .

71. Niehuss and Fisher, supra note 3, at 23. See O'Brien v. Illinois Surcty Co., 203 Fed. 436, 439 (C. C. A. 6th, 1913).

72. A surety bond is used more frequently than a personal bond since the sum involved in the transaction is usually large. Some of the chief disadvantages of such $a$ bond are the added costs of premiums to the lessee and the requirement of the deposit of collateral. Wilson, supra note 69 , at 429 . An example of a surety bond provision can be found in Halstead v. Globe Indemnity Co., 138 Misc. 717, 246 N. Y. Supp. 601 (Sup. Ct. 1930).

73. Security deposits have developed with the rise of long term leases. See Wilson, supra note 69 , at 431 . It is interesting to note that although most ground leases contain 
whereby bonds, stocks or other securities are placed in the hands of the lessor or a trustee until completion of the building, has developed with the recent rise of the long term lease and has led to a constant stream of litigation relating to its nature and form, ${ }^{74}$ its use and investment ${ }^{75}$ by the lessor.

Closely connected with the development of the security clause of the ground lease has been the trend toward greater freedom of assignability. In earlier leases the right to assign was strictly limited, but with the development and use of stable security devices and the recognition of the advantages of freer marketability of these leases, the assignment provisions and judicial interpretation of them have been correspondingly liberalized. ${ }^{i 6}$ The lessor may provide for the release of the tenant after assignment and yet maintain a secured position either by requiring that the assignment be made only with his consent, 77 or that the assignee be one who is willing and able to assume the performance of the lease terms ${ }^{78}$ or, more frequently, that the assignment take place only after the building is erected. ${ }^{79}$ Although the general legal rule has been that the original lessee is not released from his covenant to pay

elaborate provisions for some type of security during this interim period, no instances were discovered where additional security was required to take care of the period when the building tended to become obsolete.

74. Deposit clause forms include those which treat the security as a bonus, inducement or consideration for the lease, those which treat it as rental payment and those which recognize it as what it really purports to be, a security payment. The purpose of the first two types is to create an absolute transfer to the lessor which he is under no obligation to return upon default. In the last type, the lessor must return the excess above his actual damages. See Wilson, stpra note 69, at 439 et seq. and cases cited.

75. There are three conflicting theories here. First, the security deposit simply creates a debtor-creditor relationship and the lessor is under no duty to segregate and may make personal use of the funds. Mendelson-Silverman, Inc. v. Mralco Trading Co., 146 Misc. 215, 260 N. Y. Supp. 881 (Sup. Ct. 1932), aff'd, 262 N. Y. 621, 188 N. E. 92 (1933); Goodman v. Schached, 144 Misc. 905, 260 N. Y. Supp. $8 \$ 3$ (1932). Second, a pledge relationship is created so that the lessor cannot dispose of the deposit, though he may mingle it with his own funds or keep it in a bank Reed v. Bristol County Realty Co., 250 Mass. 284, 145 N. E. 455 (1924); Colantuoni v. Balene, 95 N. J. Eq. 748, 123 At1. 541 (1923) ; Ryan v. Stagg, 89 MLont. 390, 298 Pac. 353 (1931). Third, the deposit is a trust fund which creates a trustee-cestui relationship between lessor and lessee. Green v. Frahm, 176 Cal. 259, 168 Pac. 114 (1917); Atlas v. Moritz, 217 App. Div. 3S, 216 N. Y. Supp. 490 (4th Dep't 1926). See Comment (1933) 43 Yare L. J. 307. The confused situation in New York was remedied by the enactment of N. Y. REAL Pror. InVy $\$ 233$ which recognizes the security deposit as a trust fund.

76. Fisher and Niehuss, supra note 1, at 3; (1937) 23 VA. L. REv. 838.

77. S. S. Kresge Co. v. Sears, 87 F. (2d) 135 (C. C. A. 1st, 1936); Colten v. Todd, 130 Minn. 227, 153 N. W. 531 (1915). Cf. Gillette Bros. v. Aristocrat Restaurant, 239 N. Y. 87,145 N. E. 748 (1924).

78. Towle v. Morrell, 129 Neb. 398, 261 N. W. 827 (1935); Lindley v. Sale, 140 Cal. App. 662, 36 P. (2d) 130 (1934).

79. Gusman v. Matthews, 29 Ohio App. 402, 163 N. E. 636 (1928). Where there is no express provision in the lease against assignment, the lessee is free to assign the premises. S. Mr. Braunstein, Inc. v. McCrory Stores, 93 N. J. Eq. 419, 116 Atl. 707 (1922) ; Patterson v. Butterfield, 244 Mich. 330, 221 NT. WW. 293 (1928). 
rent by assignment of the lease to a third party, ${ }^{80}$ there has been an indication that the courts may accord the long term lease individual treatment by implying a release of personal liability where the circumstances indicate that the lessor was looking primarily to the building or security deposit as the security for the rent, or where a right to sublet has been accorded by the lease. ${ }^{81}$

The availability of an option to purchase the fee during the course of the term is necessarily dependent upon the owner's willingness to part with the property. But if the lessee can obtain such an option, he has a safety valve through which he may relieve himself of the obligations of the lease should they prove overburdensome. ${ }^{82}$ When the lease is accompanied by this feature, it is much easier to borrow on the basis of the leasehold interest, for by exercise of the option, a first leasehold mortgage automatically becomes a first mortgage on the fee. ${ }^{83}$ The other situation in which the option to buy is of importance occurs at the natural termination of the lease. If, as anticipated, security clauses make the lease relationship more permanent in character, the problem of disposition of the improvements will demand more attention in the future: Most of the leases that have expired to date have made no provision and the improvements have reverted to the lessor without compensation to the lessee in accordance with the established common law rule. ${ }^{84}$ This rule, it is claimed, retards the making of new improvements or the repair and maintenance of existing ones as the end of the term approaches, thereby impairing the owner's security. ${ }^{85}$ In a number of leases, the suggestion has been made and adopted that the initial option be given the lessor to buy the improvements at an appraised value, and if such is not exercised, that an option be given to the lessee to purchase the fee. If neither desires to exercise his option, provisions can be incorporated in the lease either for indefinite renewal of the term, or for tenancy in common in proportion to the respective interests of lessor and lessee. ${ }^{86}$ One legal obstacle which con-

80. Abrahamson v. Brett, 143 Ore. 14, 21 P. (2d) 229 (1933). Cf. Kanawha-Gawley Coal Co. v. Sharp, 73 W. Va. 427, 80 S. E. 781 (1914).

81. Alexander v. Theatre Realty Corp., $253 \mathrm{Ky} .674,70 \mathrm{~S}$. W. (2d) 380 (1934); (1937) 23 VA. L. Rev. 838. It has been argued, with little success to date, that the fact the parties made a long term lease indicates by its very nature that they intended an assignment to release the original lessee. Id. at 839.

82. BINGHAis AND ANDREws, op. cit. supra note 27, at 40, 42. In Detroit, there was but one lease in the 26 recorded between 1834 and 1910 that had an option to purchase clause. Between 1921 and 1929, in 37 of the 113 recorded leases, such a clause was included. Fisher and Niehuss, supra note 1, at 2, 5.

83. Chapman v. Great Western Gypsum Co., 216 Cal. 420, 14 P. (2d) 758 (1932). But cf. Vansant v. Hartman, 88 Wash. 636, 153 Pac. 1062 (1915).

84. The Detroit study indicated that 307 of the 313 recorded leases allowed the improvements to revert to the lessor free of charge. Fisher and Niehuss, supra note 1, at 3,5 .

85. Niehuss and Fisher, supra note 3 , at 31 .

86. The advantages and disadvantages of these suggested methods of dealing with the problem are discussed in Niehuss and Fisher, supra note 3 , at 32 et seq. Where the 
fronts an option to purchase clause is the possibility that it may violate the Rule against Perpetuities; but the sparse authority in this country indicates that the Rule is not violated, since an option attached to a lease is an aid and encouragement to the alienability of the property..$^{8 T}$

In the last analysis, the biggest legal problem in making these leases economically justifiable is one of draftsmanship, for the financing and the free transferability of business property can be accomplished only if the long term lease is based upon a carefully drawn document. ${ }^{85}$ Two illustrations suffice to show how important this problem may become. In Alcrander $\boldsymbol{v}$ Theater Realty Company,89 a lessor throughout the lease negotiation had insisted upon a $\$ 250,000$ security deposit, but had indicated no interest in the personal responsibility of the lessee corporation. When the market collapsed in 1929, the lessee, unable to meet rentals, assigned the lease to a straw corporation solely for the purpose of ridding itself of liability. Under these circumstances, the court held that the original lessee was relieved of liability since the assignment clause did not contemplate personal responsibility. By inserting a stipulation that the consent of the lessor be obtained before assignment, or that assignment could only be made to one financially responsible, the lessor could have been protected. In Palterson v. Bullerfield ${ }^{90}$ the tenant was obligated to tear down an old building on the premises and erect a new one within ten years. The lessee, contemplating the erection of a theater, destroyed the old building a few months after the lease became effective. Then theatrical conditions changed and the lessee temporarily abandoned the idea of erecting the new building. His security impaired, the lessor brought suit, and maintained that a new building must be ereeted immediately. But the court held that if such was the contemplation of the partics, a provision to that effect could have easily been inserted in the lease, and though the lessor's security was impaired and surrounding properties held by him were

appraisal method is used and the appraisers, without fault of either landlord or tenant, failed to make the appraisal before the expiration of the term, the lessor's option remained open and the lessee could continue in possession until the appraisal was made. Columbia University v. Kalvin, 250 N. Y. 469, 166 N. E. 169 (1929).

87. Hollander v. Central Metal Co., 109 M1d. 131, 71 Atl. 442 (1908). Cf. Prout v. Roby, 15 Wall. 471 (U. S. 1872) (option upheld without discussion). Sce Abbott, Leases and the Rule Against Perpetuities (191S) 27 YaLE I. J. 878. The English eases are contra. Woodall v. Clifton, $2 \mathrm{Ch} .257$ (1905); Worthing Corp. v. Heather, $2 \mathrm{Ch}$. 532 (1906).

88. The flexible nature of the lease makes it possible for the parties to adapt it to their wishes. Lewrs, Long Terar Leases (1930) 3. See White, Practical Considcrations in the Drawing of 99-Year Leases (1921) 18 Onio L. REP. 311. One of the present drawbacks to the long term lease is its sheer physical length. Only by a process of crystallization of both law and expression can the length of the instrument be cut down. If brevity is attempted, the lawyer will always be faced with the counter consideration that it is in its flexibility that the efficacy of the lease lies.

89. $253 \mathrm{Ky} .674,70 \mathrm{~S}$. W. (2d) 380 (1934).

90. 244 Mich. 330, 221 N. W. 293 (1928). 
adversely affected, the primary objective was to allow the lessee to finance the undertaking at any time during the ten year period. Careful draftsmanship of the lease instruments would have removed the basis for such litigation.

The long term ground lease has provided a flexible credit device for building erection in larger cities. Though it has suffered along with other methods of financing in times of temporary economic stress, it has been established over a prolonged period as a workable and fairly efficient clevice. Properly controlled and drawn to fit the needs of both parties, it creates interests which are readily saleable and thus tends to promote freer transferability of land.91 With the growth and expansion of business districts in the smaller cities, its future usefulness should become even more widespread, its popularity more assured.

91. See Levy, Long Term Leases and the Broker, Proceedings, Broken's Division, National Real Estate Board (1924) 22, 25. There is, however, vigorous dissent from the contention that the long term lease creates readily transferable interests, on the ground that it enables the owner to hold the land indeterminately, enjoy the rent: and prosper at the expense of those who develop the land. Unpublished Commentary on Long Term Leases by the WPA Project on All Laws Affecting Real Estate, No. 465-97-3-46. The argument is sustained to some extent by the fact that some of New York's most valuable properties have been held in one family for generations. See generally Pound, The Golden Earth (1935). 